\title{
Treatment of Graft-versus-Host Disease with Naturally Occurring T Regulatory Cells
}

\author{
Piotr Trzonkowski · Anna Dukat-Mazurek • Maria Bieniaszewska • \\ Natalia Marek-Trzonkowska • Anita Dobyszuk · Jolanta Juścińska • \\ Magdalena Dutka $\cdot$ Jolanta Myśliwska $\cdot$ Andrzej Hellmann
}

Published online: 28 June 2013

(C) The Author(s) 2013. This article is published with open access at Springerlink.com

\begin{abstract}
A significant body of evidence suggests that treatment with naturally occurring $\mathrm{CD} 4{ }^{+} \mathrm{CD} 25^{+} \mathrm{T}$ regulatory cells (Tregs) is an appropriate therapy for graftversus-host disease (GvHD). GvHD is a major complication of bone marrow transplantation in which the transplanted immune system recognizes recipient tissues as a non-self and destroys them. In many cases, this condition significantly deteriorates the quality of life of the affected patients. It is also one of the most important causes of death after bone marrow transplantation. Tregs constitute a population responsible for dominant tolerance to self-tissues in the immune system. These cells prevent autoimmune and allergic reactions and decrease the risk of rejection of allotransplants. For these reasons, Tregs are considered as a cellular drug in GvHD. The results of the first clinical trials with these cells are already available. In
\end{abstract}

P. Trzonkowski $(\bowtie) \cdot$ A. Dukat-Mazurek · A. Dobyszuk Department of Clinical Immunology and Transplantology, Medical University of Gdańsk, Ul. Dębinki 1,

80-211 Gdańsk, Poland

e-mail: ptrzon@gumed.edu.pl

M. Bieniaszewska · M. Dutka · A. Hellmann Department of Hematology and Transplantology,

Medical University of Gdańsk, Gdańsk, Poland

N. Marek-Trzonkowska

Department of Family Medicine, Medical University of Gdańsk, Gdańsk, Poland

J. Juścińska

Regional Center of Blood Donation and Treatment,

Gdańsk, Poland

J. Myśliwska

Department of Immunology, Medical University of Gdańsk, Gdańsk, Poland this review we present important experimental facts which led to the clinical use of Tregs. We then critically evaluate specific requirements for Treg therapy in GvHD and therapies with Tregs currently under clinical investigation, including our experience and future perspectives on this kind of cellular treatment.

\section{Graft-versus-Host Disease (GvHD)}

Graft-versus-host disease (GvHD) is a complication of allogeneic hematopoietic stem cell transplantation, in which donor immune cells recognize and attack host tissues. It may occur within the first 100 days after allotransplantation as acute GvHD. Acute GvHD manifests as inflammatory lesions in a single or many locations, the most common of which are skin, gut, and liver. The progression of acute GvHD may be very rapid and the disease can be fatal within days or weeks. The onset of GvHD beyond 100 days is classified as chronic. There are some common features of the acute and chronic forms of GvHD but the majority of the symptomatology and pathogenesis are different. Chronic GvHD resembles autoimmune systemic diseases with a long progression, such as lupus or scleroderma.

The classical paradigm assumes that there are several conditions that must be fulfilled in order to initiate GvHD. The graft must contain mature immunocompetent lymphocytes which recognize host tissues as non-self antigens and the host is unable to reject the graft [1].

Decades ago, elegant animal studies revealed important biological features of GvHD relevant for its treatment. Studies with inbred mice proved involvement of $\mathrm{T}$ cells in this process with a dominant role of antigen mismatches. In animal models, mismatches in major histocompatibility 
complex (MHC) were the most obvious. The number of mismatches significantly enhances effector responses as mismatched MHCs activate the immune system 100-1,000 times more strongly than bacterial epitopes [2]. For example, a classical mice bone marrow (BM) transplantation experiment with $\mathrm{C} 57 \mathrm{BL} / 6\left(\mathrm{H}-2^{\mathrm{b}}\right)$ strain as a donor and B10.BR $\left(\mathrm{H}-2^{\mathrm{k}}\right)$ strain as a recipient guaranteed an MHC incompatibility model in which $\mathrm{MHC}$ mismatch was shown to be a leading cause of the onset of GvHD [3]. BM transplantation experiments limited to MHC class II mismatches proved that $\mathrm{CD}^{+}{ }^{+} \mathrm{T}$ cells could independently trigger lethal GvHD [4]. At the same time, $\mathrm{CD}^{+} \mathrm{T}$ cells were probably less important as isolated class I mismatches resulted in milder forms of the disease than similar class II mismatch models. However, the number of transplanted cells corrected for this imbalance and higher numbers of transplanted mismatched $\mathrm{CD}^{+} \mathrm{T}$ cells could also be a cause of lethal GvHD [5]. MHC receptors could trigger GvHD also via interaction with receptors on natural killer (NK) cells [6-8]. Yet another part of this story lies in incompatible minor antigens that are different to MHC. It was proven that they were able to sensitize the donor against recipient cells that triggered lethal GvHD. In fact, minor antigen models are probably closer to human pathology than MHC ones as strict MHC matching is a rule in the current clinical practice. Interestingly, the predominance of either $\mathrm{CD}^{+}{ }^{+}$or $\mathrm{CD}^{+}{ }^{+} \mathrm{T}$ cells in the development of the condition triggered with minor antigens depended on particular mismatches [9].

In the majority of animal studies, GvHD could only be triggered when the host was conditioned prior to $\mathrm{BM}$ transplant in order to destroy its own immunity. Otherwise, residual host immunity was always the cause of a threat of graft rejection instead of a GvHD reaction [10, 11]. Conditioning is a non-immunologic insult to the tissues. The intensity and toxicity of conditioning was found to be proportional to the grade of GvHD and different forms of conditioning could drive particular manifestations of the disease [12]. Hence, it was recognized as an independent risk factor of GvHD. Non-immunologic factors are even more important in humans, where the transplants cannot be designed and strictly controlled, like in animal inbred models. Hence, non-immunologic factors in humans take significant part of the stage. Apart from the toxicity of conditioning, primary disease, infections, and saprophytic flora were included to this group of factors. Tissue injury caused by conditioning was able to ignite GvHD alone through produced danger signals, such as chemokines, proinflammatory cytokines, content released from damaged cells and, most prominently, microbiota from the damaged gastrointestinal tract of the host $[12,13]$. It has been found that this environment stimulated antigen presenting cells (APCs), mainly dendritic cells (DCs), to present antigens and initiate immune response. Importantly, host DCs without the need of recipient DC involvement were sufficient to mediate this early phase of GvHD [12, 14]. Antigens presented by DC activated T cells, which proliferated, acquired effector characteristics and attacked host tissues. The inflammatory environment in GvHD was also boosted by $\mathrm{DC}-\mathrm{T}$ cell interactions. Cooperation of these cells in GvHD was responsible for a significant increase in the secretion of cytokines with tumor necrosis factor (TNF)- $\alpha$, interferon (IFN)- $\gamma$, interleukin (IL)-1, and IL2 among the most important soluble factors [15]. Clinical onset of GvHD took place relatively late. The effector phase usually manifested when activated $\mathrm{T}$ cells were already expanded and trafficked through the tissues.

Together, these classical studies showed that prevention of GvHD should include perfect MHC match (preferably in ten $\mathrm{MHC}$ alleles), donation from relatives (minor antigens match), depletion of mature lymphocytes from the transplanted material, and immunosuppressive prophylaxis during the first post-transplant months.

\section{Biology of T Regulatory Cells (Tregs) Relevant for GvHD}

Nevertheless, another attractive treatment opportunity exists naturally in the body. T regulatory cells (Tregs) are a small subset of $\mathrm{CD}^{+} \mathrm{T}$ cells-no more than $1 \%$ of peripheral leukocytes-which protect our bodies from aberrant autoaggressive immune responses of effector cells acting against self-tissues. In our experience, Tregs could protect against GvHD after transplantation of peripheral blood stem cells. We have found that recipients of leukapheresis product enriched with a high number of $\mathrm{CD} 4{ }^{+} \mathrm{CD} 25^{+}$Tregs were less likely to develop acute GvHD. Moreover, the onset of GvHD was less likely to occur in the recipients whose donors were characterized by a high number of Tregs in the peripheral blood. In our opinion, the suppressive effect of Tregs in the recipients in this study was mainly related to the suppression of $\mathrm{NK}$ cells and decreased production of IL-2 [8].

Tregs are usually divided into naturally occurring Tregs and adaptive Tregs [16]. It has been agreed that natural Tregs are more potent and specifically dedicated to regulatory function, notably in GvHD [17, 18]. These cells are generated in the thymus. Initially, naturally occurring Tregs were identified as autoreactive $\mathrm{CD}^{+}{ }^{+} \mathrm{T}$ cells which escape negative selection and reveal an extraordinary pattern of activity. Namely, Tregs become anergic when they recognize self-antigens and quench the immune response of other immune cells under these conditions [19]. Further studies confirmed that self-reactivity of $\mathrm{T}$ cell receptors (TCRs) expressed on Tregs is important for the 
commitment of this lineage in the thymus, but the repertoire of TCRs on mature Tregs is similar to T effector cells [20]. The selective pressure in the thymus is probably a low avidity of TCRs expressed on developing Tregs, which allows the selection of Tregs specific for autoantigens but also for some alloantigens. No doubt, this is of great importance in the transplantation setting. Tregs reveal suppressive activity after engagement of their TCRs with antigens presented on APCs [21,22]. Tregs compete for autoantigens on APCs in the periphery and, unlike T effector cells, impose anergy when a matching autoantigen is encountered. This mechanism is also important in the prophylaxis of GvHD in the clinic since donor-recipient pairs are fully matched in MHC alleles and host antigens should be recognized by transplanted donor Tregs as self. Low avidity of TCRs on Tregs may be additionally advantageous when some mismatches are present as the specificity of TCRs should then cover the majority of the host epitopes and responses against recipient tissues are suppressed. TCR-dependent suppression is antigen-specific but Treg-APC interaction also quenches responses to other antigens presented by APC at the inflammation site. This is called bystander activation and additionally protects the recipient from reactions ignited by $\mathrm{MHC}$ and non-MHC mismatches [23]. Considering high expression of adhesive molecules and integrins on Tregs $[24,25]$, these cells traffic to inflamed tissues faster than $\mathrm{T}$ effector cells. When self-antigens released from damaged cells are recognized, Tregs initiate an anergic state before any $\mathrm{T}$ effector cells are present. Under these conditions, $\mathrm{T}$ effector cells migrating to the inflammation site later than Tregs cannot be activated. From this angle, Treg-oriented therapies should be especially useful in the prophylaxis of GvHD as Tregs keep tolerance to the matched host tissues but they can also react across MHC barriers and prevent the initiation of immune responses to host antigens, even when tissue injury after conditioning or infection is present.

Nevertheless, suppression of ongoing responses by Tregs is also possible. When Tregs and $\mathrm{T}$ effector cells interact with APC in equal numbers, it is the Tregs which prevail. This is due to the co-stimulatory blockade exerted by CTLA-4 molecule (cytotoxic T-lymphocyte antigen 4; CD154) expressed on Tregs, which is a ligand of B7 receptors on APC. The CTLA-4 receptor has around 20 times higher affinity to B7 receptors than its homolog CD28 receptor expressed on T effector cells [26]. Unlike CD28 receptor, the engagement of CTLA-4 significantly suppresses antigen presentation and any ongoing immune responses and therefore it is recognized as a major suppressive molecule on Tregs [27]. High effectiveness of the receptor has already translated into biological drugs. Fusion proteins containing the sequence of CTLA-4, abatacept and belatacept, are already registered as immunosuppressive pharmaceuticals for maintenance therapy in solid organ transplantation [28]. Unfortunately, they were tried as GvHD prophylaxis in preclinical models of BM transplantation with limited success as they have no activity against NK cells [29]. For this reason, cellular therapy with alive Tregs is of more interest in hematological transplantations as these cells utilize a variety of suppressive pathways. For example, Tregs are able to suppress NK cells in a cell-to-cell interaction via surface transforming growth factor (TGF)- $\beta$ and lymphocyte-activation gene 3 (LAG3) [30, 31]. Activated Tregs secrete perforin and granzymes and kill activated effectors around them $[32,33]$. Tregs utilize extracellular adenosine and cyclic adenosine monophosphate (cAMP) to inhibit effectors via $\mathrm{A} 2 \mathrm{~A}$ receptors but also by the transfer of the latter metabolite through gap junctions to $\mathrm{T}$ effector cells [34, 35]. Finally, Tregs 'steal' IL-2 from inflammatory surroundings (CD25 is an IL-2 receptor expressed on Tregs at the highest possible level), 'starving' T effectors, which as a result undergo apoptosis [36]. IL-2 is important for the functioning of mature Tregs but it is equally necessary for their thymic development [37]. Recent clinical trials revealed that the administration of IL-2 in the recipients of hematopoietic cell transplants was associated with preferential, sustained Treg expansion in vivo and amelioration of chronic GvHD in a substantial proportion of patients $[38,39]$. This effect could be additionally enhanced with rapamycin, which is believed to induce Tregs. Simultaneous administration of rapamycin with IL-2 protected from acute GvHD in an animal model of BM transplantation and this effect was associated with increased levels of Tregs [40].

When looking into biological features of Tregs useful for treatment, their local mode of activity should be especially pinpointed. Tregs are characterized by three very unique features which are related to the local mode of action - they actively traffic to the inflammation site, exert suppressive abilities only on activation, and this action is mainly cell-to-cell dependent [30]. Thanks to that, they actively search for inflamed tissue, suppress only when inflammation occurs, and their activity is precisely limited to the inflammation site. These features limit possible adverse reactions, which are important drawbacks of the current immunosuppression therapies. This mode of action makes Tregs 'intelligent steroids', with all benefits and almost no disadvantages known from other forms of immunosuppressive therapies.

\section{Animal Models of Intervention with Tregs in GvHD}

The mechanism of action of Tregs makes them a very good candidate for cellular therapy of GvHD. Proof-of-concept 
studies verifying their usefulness were initially performed in animals. Depletion of Tregs from transplanted material was associated with lethal GvHD, while the addition of donor Tregs at the time of grafting significantly delayed or prevented GvHD [41, 42]. The protective effect of Tregs was dose dependent [43] but equally important was the ability of Tregs to traffick through the body. The experiments proved that GvHD did not occur only if transplanted Tregs expressed the CD62L receptor necessary by them for trafficking between blood and lymphoid tissue [44]. Hence, the CD62L receptor is currently recognized as a marker of functional suppressive Tregs, both in mice and humans.

Animal models also revealed that specificity of Tregs is important in protection from GvHD. Although both polyclonal and recipient-specific Tregs enabled GvHD-free survival of the animals after BM transplantation, Tregs specific for recipient alloantigens were significantly better in maintaining the welfare of transplanted animals [45]. Additionally, Tregs specific for recipient alloantigens favored immune reconstitution and graft versus leukemia (GvL) responses, which were hardly seen in the case of polyclonal Tregs [46].

Finally, ideas regarding expansion were tested initially in animals. Since the number of Tregs in the body is very low, a realistic approach to the therapy should assume their expansion to much higher numbers prior to administration to the recipient. Initial experiments with animals proved that such an approach is feasible and expansion of Tregs can be achieved ex vivo [45].

\section{Tregs as a Drug}

For obvious reasons, translation of any cellular therapy from animal models to human therapy is very much restricted by clinical regulations and safety of the patients. The laboratories in which cellular products are prepared, so-called cleanrooms, must contain a specific controlled environment. This environment is mainly an easily-cleanable design, a system of high-efficiency particulate air (HEPA) filters and air-locks providing ultra-pure air, validated equipment and reagents for the product preparation, and a controlled manufacturing system of production (GMP-good manufacturing practice). Production of clinical grade Tregs has three critical steps: isolation, expansion, and quality control.

Isolation/sorting is usually performed in either closed or opened systems. A closed system is mainly based on immunomagnetic sorting in which anti-Treg monoclonal antibodies are conjugated to ferromagnetic corpuscles and therefore separation of the cells of interest occurs due to the magnetic field [47]. The mixture of cells is stained with the antibodies in a closed bag and the bag is placed in a magnetic field. The cells with magnetic corpuscles bound on the surface are kept in the field while non-stained cells are flushed out from the bag. This kind of preparation is very easy to perform, the procedure is fast (no longer than a couple of hours), and it is performed in a closed system that does not require the use of cleanroom area at this stage. Theoretically, it can be performed in almost any laboratory of clinical hematology. Disadvantages of this system are mainly limited to the number of markers that can be used for isolation, and therefore low purity of the post-sort population. The opened system is usually based on fluorescence-activated cell sorters (FACS sorters), in which cells are stained with a cocktail of Treg markers-antibodies conjugated to fluorochromes emitting fluorescence-and sorting occurs in a strong electric field [48]. The cells flow in an open stream divided into small droplets. If the droplet contains the cell of interest-which is detected by fluorescence of the antibodies excited with lasers in the sorter-it is charged, deviated from the main stream, and collected in a dedicated separate dish. This strategy allows for sorting with simultaneous staining with many markers. Importantly for Tregs, the basic surface phenotype of which is $\mathrm{CD} 3{ }^{+} \mathrm{CD} 4^{+} \mathrm{CD} 25^{\text {high }} \mathrm{CD} 127^{\text {low/neg- }}$ ative, the cells with various density of expression of particular surface markers can be sorted. Finally, post-sort purity is extremely high. These two advantages may be of special interest in BM transplant patients, whose health status is not satisfactory and whose frailty also affects leukocytes including Tregs [49-51]. Additional markers used for sorting may then allow for selection of fully functional Tregs only. A disadvantage of the method is the long time necessary for sorting and the need for placing the whole procedure in a cleanroom environment, including additional requirements for the design of the sorters. From a clinical point of view, important also is that the immunomagnetic sorting is already approved for routine clinical practice, while FACS sorters are allowed only for earlyphase clinical studies, with separate agreements needed for particular studies (for examples, master files for FACS sorters can be found with the US FDA). Nevertheless, recently released generation of FACS sorters equipped with exchangeable sample lines, HEPA enclosures, UV lamps, and air and fluid filters already fulfill the requirements necessary to receive permission for routine use in the clinic $[52,53]$.

Sorted Tregs need to be expanded as the post-sort yield is usually very low. For example, in our studies the yield from half a liter of drawn peripheral blood might be as low as $1 \times 10^{5}$ of Tregs [54]. It can be slightly improved by the use of leukapheresis products instead of peripheral blood [55]. Very interesting is the use of umbilical cord blood (UCB), which can efficiently be expanded without losing regulatory capabilities [56]. UCB and probably 
UCB-derived Tregs can be transplanted without strict human lymphocyte antigen (HLA) matching requirements, which increases availability of this product for potential GvHD recipients. Moreover, it has been revealed in an animal model of solid organ transplantation that, like in the case of UCB transplantations, it is possible to pool Tregs from several units of UCB for a single recipient [57]. Treg expansion is performed exclusively in a cleanroom with clinical-grade reagents [58]. The majority of the laboratories perform it in a high concentration of IL-2 (300-1,000 UI/mL) in the presence of anti-CD3 and antiCD28 antibodies which stimulate proliferation of Tregs [54]. Currently, these antibodies usually coat plastic beads and such constructs mimic APCs and interact with Tregs. Under these conditions, Tregs can be multiplied between 100 and 1,000 times, up to $1-10 \times 10^{9}$ Tregs, within the 2 weeks allowed for the expansion. Proper selection of markers for sorting, media, bead:cell ratio, and the time of expansion allow the stable suppressive function of Tregs to be kept intact at the end of expansion [58, 59]. The novel method proposed for expansion is based on an alive APC analog-K562 cells engineered to express CD86 and CD64 receptors. The addition of these irradiated APCs to the expansion culture increased the final yield up to an impressive 3,000 times and allowed for the yield of more than $600 \times 10^{9}$ Tregs with preserved phenotype and suppressor function [60]. Some laboratories, especially those using immunomagnetic sorting with an impure postsort product, add compounds selecting preferentially for Tregs, such as rapamycin, to the expansion cultures in order to selectively activate proliferation of Tregs and inhibit proliferation of $\mathrm{T}$ effector cells [61]. Nevertheless, at least in our experience, the addition of rapamycin severely decreased the number of expanded Tregs.

As a clinical-grade product, expanded Tregs need to be carefully examined during the entire production process and before they are released from the laboratory to the patients. This includes mainly two kinds of tests: quality and contamination checks. Quality tests usually consist of a phenotype check and functional assays. As compared with sorting, using a phenotype check for quality is more complex as it also contains intracellular markers, such as FoxP3 and Helios, which are recognized currently as the most specific markers of natural Tregs [62]. In our laboratory the release criterion is the percentage of FoxP3positive Tregs at the end of expansion: $\geq 65 \%$ for adults and $\geq 75 \%$ for children. It is of note that, without problems, it is usually much higher at the end of expansion and the level of Helios usually follows that of FoxP3. In the available literature, the level for Tregs harvested immunomagnetically is usually $\geq 50 \%$. Functional assays usually check the suppressive ability of Tregs. The most classical is mixed lymphocyte reaction (MLR) with responder cells mixed with irradiated allogeneic stimulators and serial titration of expanded Tregs. In this setting, Tregs should suppress proliferation of responder cells proportionally to the number in particular wells of reaction [63]. A non-radioactive alternative is a CFSE (carboxyfluorescein succinimidyl ester)-based suppression assay in which responders are stained with CFSE and dilution of the dye visualized with flow cytometry is inversely correlated with the suppression of proliferation [58]. In both methods, the result is available a few days after the test is commenced, when Tregs may already have significantly changed their activity. Hence, these tests are not feasible for the release of clinical products. A fast alternative may be a test that measures Treg-mediated inhibition of cytokine release by responders instead of suppression of proliferation. Developed in our laboratory, it requires no more than a few hours in order to obtain the result [30, 59, 64]. Another rapid test is based on Treg-mediated suppression of the expression of activation markers CD69 and CD154 on responder $\mathrm{T}$ cells [65]. The microbiology test usually consists of standard anaerobic and aerobic cultures, immediate gram-staining, checks for genetic material of hepatitis $\mathrm{B}$ virus, hepatitis $\mathrm{C}$ virus, HIV, cytomegalovirus, and Treponema pallidum, and GMP-specific checks for the contamination of the product and/or laboratory equipment with endotoxin and mycoplasma. At least in our laboratory, quality and contamination checks are also performed during expansion of Tregs.

\section{Clinical Trials with Tregs}

Although clinical trials with Tregs take their first steps in the clinic, they can be divided into two main streams: prophylaxis or treatment of ongoing disease. Our experience is gained from the latter. We were the first center to translate Tregs to human therapy. This was restricted by some specific rules, such as proof of safety with injection of a small amount of Tregs in healthy volunteers, including myself (PT). In patients, we were allowed to administer Tregs only as a rescue therapy, if other forms of therapy were ineffective and the progression of GvHD put the patient in danger of fatal complications. Finally, we needed to obey dose-escalating rules starting from small doses of Tregs, such as $1 \times 10^{5}$ per kg body weight. All of these requirements significantly narrowed the cohort of patients to whom the therapy could be administered. In addition, relatively strict release criteria excluded many expanded Tregs products ranked below the threshold. The main idea of the trial was the transfer of pure Tregs from healthy donors to recipients with diagnosed severe forms of GvHD. Tregs were FACS sorted from the unit of peripheral blood. Thanks to that, the cells administered to the patient were 
characterized by only minimal impurity of other subsets. This is very important from the pharmacologic point of view, where well-defined product is the priority. In our experience, sorting always gave a purity above $95 \%$ of FoxP3-positive Tregs, and discarding of the product happened only if FoxP3 levels dropped below the threshold during the expansion. The two patients described in our first paper actually confirmed the general rule for the therapy with Tregs in humans-it is effective in the treatment of chronic GvHD and ineffective in accelerated forms (grade IV) of acute GvHD [66]. Infusion of even a small dose of Tregs $\left(1 \times 10^{5}\right.$ cells per kg body weight with a high purity equal to $90 \%$ of FoxP3 $3^{+}$cells) permitted us to withdraw the majority of pharmacologic immunosuppression and allowed symptom relief in a patient with chronic GvHD. This was associated with an increase in the number of Tregs in the periphery. Unfortunately, we observed only transient improvement in acute GvHD and the patient eventually died. Infusion of higher doses of Tregs $\left(5-10 \times 10^{6}\right.$ per kg body weight $)$ in other chronic GvHD patients recruited in the trial confirmed the effectiveness of this therapy. However, we observed relapses of GvHD symptoms after various periods of time in some patients (unpublished data). We performed two more attempts in patients with grade IV acute GvHD; unfortunately, in both cases GvHD further progressed and the patients died. We now believe that the prophylaxis rather than the treatment of the late phase of acute GvHD is beneficial. It should be taken into account that the time from a decision to the point of infusion is around the 2 weeks necessary for the expansion of Tregs. This is too long a waiting time for a condition with rapid progression, such as acute GvHD. Tissue damage which occurs within 2 weeks, notably in uncontrolled grade III-IV acute GvHD, triggers many nonimmunologic mechanisms that cannot be stopped by expanded Tregs at this point. In our study, we have not observed any Treg-related adverse effects during the infusion or post-infusion follow-up in any of the patients so far. In fact, as the number of patients was very low, the main conclusion of this trial is good safety of the administration rather than efficacy. This is probably the only strong conclusion from all available studies with Tregs as all of them together have included no more than 100 patients.

Three other trials with natural Tregs which have published results recently are interesting as Tregs were applied as a prophylaxis of GvHD. In the trial by Di Ianni et al., fresh donor Tregs $\left(2-4 \times 10^{6}\right.$ Tregs per $\mathrm{kg}$ body weight $)$ were administered immediately after immunomagnetic separation to 26 recipients as a part of a BM transplant procedure at day -4 before the transplantation [67]. Technically important is that two separations failed as the purity of fresh product was too low $(\leq 50 \%)$. Median purity of the administered products was $69.2 \%$. At day 0 patients received an HLA-haploidentical $\mathrm{CD}^{+} 4^{+}$cells transplant and donor lymphocyte infusion consisting of $\mathrm{T}$ effector cells $\left(0.5-4 \times 10^{6} \mathrm{~T}\right.$ cells per $\mathrm{kg}$ body weight $)$ as a part of GvL immunotherapy. Importantly, no pharmacologic immunosuppression was administered afterwards, which makes this study of particular interest as a proof-ofconcept for Tregs in the clinic. Interestingly, fatal acute GvHD developed only in two patients who received the highest dose of Tregs $\left(4 \times 10^{6}\right.$ Tregs per kg body weight $)$ but the authors explained that these patients also received high numbers of $\mathrm{T}$ effectors $\left(2 \times 10^{6} \mathrm{~T}\right.$ per $\mathrm{kg}$ body weight). Among 13 patients who survived for 12 months, nobody developed GvHD, which confirmed the importance of this subset in GvHD prophylaxis. There were also some additional observations exclusive to this trial. For example, the authors noted better reconstitution of $\mathrm{T}$ effector cells specific to opportunistic pathogens when compared with standard haploidentical transplants. This effect was probably not relevant for the clinic as the majority of fatal outcomes in the trial were still associated with infections. On the other hand, Tregs did not impair immune responses as five of seven study participants who were immunized against the flu showed relatively good serologic responses. In addition, Tregs did not impair GvL, which was implied by the fact that the recipients were at high risk of relapse and only one relapse was noted.

In another study, prophylaxis of GvHD with Tregs was adjuvant to standard schemes of prophylactic immunosuppression. It was performed with Tregs isolated from UCB in patients receiving a transplant with double partially matched UCB units [68]. Tregs were isolated using the immunomagnetic method and cultured with anti-CD3/anti$\mathrm{CD} 28$ beads for 1 day prior to the infusion. In some patients, Tregs were cryopreserved and a second dose was administered on day +15 . Nevertheless, cryopreservation was discouraged by the authors as the number of available Tregs after the procedure was low and they did not persist for long in the circulation. The total dose was $0.1-3.0 \times 10^{6}$ Tregs per kg body weight. Technically, in several cases Treg manufacturing did not allow enough cells to be achieved and a full dose of Tregs could not be administered. The FoxP3 level seemed not to be a release criterion as some patients received the product with only $20 \%$ purity. From our experience, the impurity and general condition of the patients might have an impact on the fast disappearance of these cells from the circulation that was reported by the authors. It occurred within 14 days after infusion. Importantly, the study once again confirmed the safety of the procedure. When compared with controls, patients treated with Tregs were better protected as acute GvHD developed in 61 versus $43 \%$ of patients, respectively. However, this result was critically evaluated in the 
comment to this article [69]. On the other hand, the author of this comment stressed the importance of safety results.

The last available trial was performed with fresh immunomagnetically isolated donor Tregs transferred [up to $5 \times 10^{6}$ cells per $\mathrm{kg}$ body weight $\left.\left(>50 \% \mathrm{FOXP}^{+}\right)\right]$into recipients after the cessation of pharmacologic GvHD prophylaxis. Due to the high risk of leukemia relapse, another donor lymphocyte infusion with $\mathrm{T}$ effector cells only was repeated in order to stimulate GvL effect. In all nine patients, GvHD was not observed. No adverse effects of infusion, severe infections, or primary disease relapses were reported [70].

\section{Conclusions}

Each of the published trials with Tregs in GvHD has an important input into our experience with these cells in the clinic. It has to be repeated that the infusion of Tregs appears to be safe. This was not as obvious a few years ago, at the time of our first attempts with Tregs, when safety concerns with the Treg-stimulating antibody TGN1412 were reported in humans [71]. Long-term follow-up studies, which are now available, have not revealed any severe adverse effects directly related to the infused Tregs. Hence, it is probably now the time to commence randomized, controlled, preferably multicenter, trials in order to assess the efficacy of therapy with Tregs. If performed from this angle, future studies should allow estimation of effective doses and improved schemes of administration of Tregs. Efficacy can also be improved with better manufacturing of the cells. In our opinion, the purity of the final product is of great importance for this area of research. From the pharmacologic point of view, defined pure product allows for reliable estimation of the dose. Recounting of effective doses with correction on the percentage of Tregs in the product, when it is impure, is not enough as the cells consisting of the impurity may significantly modify the activity of the whole preparation. Secondly, the source of Tregs will definitely have an important impact on the availability of this therapy. Autologous or donor separations are not always viable options as the condition of the patient may not allow for drawing of autologous blood and a donor is often unavailable for logistical reasons. From this point of view, UCB seems to be an attractive alternative as a source of Tregs. Availability is also the reason that different techniques of cryopreservation of Tregs should be further tested in order to make these cells a "drug on the shelf' [72]. It should be also remembered that pharmacologic agents significantly influence the activity of Tregs and future therapies should probably merge the administration of this cellular product with drugs activating Tregs. For example, rapamycin, vitamin D, retinoic acid, glucocorticosteroids, thymoglobulin, and IL-2 are among those activating Tregs, while calcineurin inhibitors are strong inhibitors of Tregs [73]. Finally, future development of therapies with Tregs will depend on regulations regarding cellular therapies. It is a novel type of treatment and there is not necessarily a fit between existing regulations and requirements of the therapy in both developmental and commercial stages. For example, in Europe Tregs are treated either as cells for transplantation or as an advanced therapy medicinal product (ATMP). In both cases, new regulations or amendments of existing regulations are now fairly common and they are usually justified by safety concerns. Taking into account that the production of cells for clinical use is already safe but very expensive, any new regulations additionally increase these costs without clear effects on safety. Hence, the balance between requirements and budget should be assessed carefully. Otherwise, we might create an innovative therapy but the majority of patients will not be able to afford it. As a tax payers, we would not tend to support such studies (and such regulations).

Acknowledgments The study was supported by the Polish National Science Center and the Polish Ministry of Science (grant numbers: DEC-2011/01/B/NZ6/00322， DEC-2011/01/D/NZ3/00262， IP2011 033771). The authors have no conflicts of interest that are directly relevant to the content of this article.

Open Access This article is distributed under the terms of the Creative Commons Attribution Noncommercial License which permits any noncommercial use, distribution, and reproduction in any medium, provided the original author(s) and the source are credited.

\section{References}

1. Billingham RE. The biology of graft-versus-host reactions. Harvey Lec. 1966;62:21-40.

2. Blattman JN, Antia R, Sourdive DJ, Wang X, Kaech SM, MuraliKrishna K, Altman JD, Ahmed R. Estimating the precursor frequency of naive antigen-specifi c CD8 T cells. J Exp Med. 2002;195:657-64.

3. Vallera DA, Carroll SF, Snover DC, Carlson GJ, Blazar BR. Toxicity and efficacy of anti-T-cell ricin toxin A chain immunotoxins in a murine model of established graft-versus-host disease induced across the major histocompatibility barrier. Blood. 1991;77(1):182-94.

4. Sprent J, Schaefer M, Korngold R. Role of T cell subsets in lethal graft-versus-host disease (GVHD) directed to class I versus class II H-2 differences. II. Protective effects of L3T4+ cells in anticlass II GVHD. J Immunol. 1990;144(8):2946-54.

5. Mowat AM, Sprent J. Induction of intestinal graft-versus-host reactions across mutant major histocompatibility antigens by $\mathrm{T}$ lymphocyte subsets in mice. Transplantation. 1989;47(5):857-63.

6. McGuinness UM, Baines MG. Augmented natural killer cell activity during neonatal graft-versus-host disease is of predominantly donor origin. Immunobiology. 1989;180(1):101-5.

7. Ferrara JL, Guillen FJ, van Dijken PJ, Marion A, Murphy GF, Burakoff SJ. Evidence that large granular lymphocytes of donor 
origin mediate acute graft-versus-host disease. Transplantation. 1989;47(1):50-4.

8. Trzonkowski P, Zaucha JM, Mysliwska J, Balon J, Szmit E, Halaburda K, Bieniaszewska M, Mlotkowska M, Hellmann A, Mysliwski A. Differences in kinetics of donor lymphoid cells in response to G-CSF administration may affect the incidence and severity of acute GvHD in respective HLA-identical sibling recipients. Med Oncol. 2004;21(1):81-94.

9. Korngold R, Sprent J. Variable capacity of L3T4+ T cells to cause lethal graft-versus-host disease across minor histocompatibility barriers in mice. J Exp Med. 1987;165(6):1552-64.

10. Blazar BR, Taylor PA, Sehgal SN, Vallera DA. Rapamycin, a potent inhibitor of T-cell function, prevents graft rejection in murine recipients of allogeneic T-cell-depleted donor marrow. Blood. 1994;83(2):600-9.

11. Knobloch C, Dennert G. Loss of F1 hybrid resistance to bone marrow grafts after injection of parental lymphocytes. Demonstration of parental anti-F1 T killer cells and general immunosuppression in the host. Transplantation. 1988;45(1):175-83.

12. Hill GR, Crawford JM, Cooke KR, Brinson YS, Pan L, Ferrara JL. Total body irradiation and acute graft-versus-host disease: the role of gastrointestinal damage and inflammatory cytokines. Blood. 1997;90(8):3204-13.

13. Matzinger $P$. The danger model: a renewed sense of self. Science. 2002;296:301-5.

14. Duffner UA, Maeda Y, Cooke KR, Reddy P, Ordemann R, Liu C, Ferrara JL, Teshima T. Host dendritic cells alone are sufficient to initiate acute graft-versus-host disease. J Immunol. 2004;172: 7393-8.

15. Welniak LA, Blazar BR, Murphy WJ. Immunobiology of allogeneic hematopoietic stem cell transplantation. Annu Rev Immunol. 2007;25:139-47.

16. Sakaguchi S, Miyara M, Costantino CM, Hafler DA. FOXP3 ${ }^{+}$ regulatory $\mathrm{T}$ cells in the human immune system. Nat Rev Immunol. 2010;10(7):490-500.

17. Koenecke C, Czeloth N, Bubke A, Schmitz S, Kissenpfennig A, Malissen B, Huehn J, Ganser A, Förster R, Prinz I. Alloantigenspecific de novo-induced Foxp3 ${ }^{+}$Treg revert in vivo and do not protect from experimental GVHD. Eur J Immunol. 2009;39(11): 3091-6.

18. Edinger M, Hoffmann P. Regulatory T cells for the prevention of graft-versus-host disease: professionals defeat amateurs. Eur J Immunol. 2009;39(11):2966-8.

19. Papiernik M, de Moraes ML, Pontoux C, Vasseur F, Penit C. Regulatory CD4 T cells: expression of IL-2R alpha chain, resistance to clonal deletion and IL-2 dependency. Int Immunol. 1998;10:371-8.

20. Pacholczyk R, Ignatowicz H, Kraj P, Ignatowicz L. Origin and T cell receptor diversity of $\mathrm{Foxp}^{+} \mathrm{CD} 4^{+} \mathrm{CD} 25^{+} \mathrm{T}$ cells. Immunity. 2006;25:249-59.

21. Sansom DM, Walker LS. The role of CD28 and cytotoxic T-lymphocyte antigen-4 (CTLA-4) in regulatory T-cell biology. Immunol Rev. 2006;212:131-48.

22. Takahashi T, Tagami T, Yamazaki S, Uede T, Shimizu J, Sakaguchi N, Mak TW, Sakaguchi S. Immunologic self-tolerance maintained by $\mathrm{CD} 25(+) \mathrm{CD} 4(+)$ regulatory $\mathrm{T}$ cells constitutively expressing cytotoxic T lymphocyte-associated antigen 4. J Exp Med. 2000;192(2):303-10.

23. Karim M, Feng G, Wood KJ, Bushell AR. CD $25^{+} \mathrm{CD} 4^{+}$regulatory $\mathrm{T}$ cells generated by exposure to a model protein antigen prevent allograft rejection: antigen-specific reactivation in vivo is critical for bystander regulation. Blood. 2005;105(12):4871-7.

24. Stassen M, Fondel S, Bopp T, Richter C, Muller C, Kubach J, Becker C, Knop J, Enk AH, Schmitt S, Schmitt E, Jonuleit H. Human $\mathrm{CD}^{+} 5^{+}$regulatory $\mathrm{T}$ cells: two subsets defined by the integrins alpha 4 beta 7 or alpha 4 beta 1 confer distinct suppressive properties upon $\mathrm{CD} 4^{+} \mathrm{T}$ helper cells. Eur J Immunol. 2004;34(5):1303-11.

25. Marski M, Kandula S, Turner JR, Abraham C. CD18 is required for optimal development and function of $\mathrm{CD} 4{ }^{+} \mathrm{CD} 25^{+} \mathrm{T}$ regulatory cells. J. Immunol. 2005;175(12):7889-97.

26. Linsley PS, Brady W, Urnes M, Grosmaire LS, Damle NK, Ledbetter JA. Coexpression and functional cooperation of CTLA4 and CD28 on activated T lymphocytes. J Exp Med. 1992; 176:1595-9.

27. Read S, Malmstrom V, Powrie F. CTLA4 plays an essential role in the function of $\mathrm{CD} 25^{+} \mathrm{CD} 4^{+}$regulatory cells that control intestinal inflammation. J Exp Med. 2000;192(2):295-302.

28. Vincenti F, Larsen CP, Alberu J, Bresnahan B, Garcia VD, Kothari J, Lang P, Urrea EM, Massari P, Mondragon-Ramirez G, Reyes-Acevedo R, Rice K, Rostaing L, Steinberg S, Xing J, Agarwal M, Harler MB, Charpentier B. Three-year outcomes from BENEFIT, a randomized, active-controlled, parallel-group study in adult kidney transplant recipients. Am J Transplant. 2012;12(1):210-7.

29. Chen Y, Fukuda T, Thakar MS, Kornblit BT, Storer BE, Santos EB, Storb R, Sandmaier BM. Immunomodulatory effects induced by cytotoxic $\mathrm{T}$ lymphocyte antigen 4 immunoglobulin with donor peripheral blood mononuclear cell infusion in canine major histocompatibility complex-haplo-identical non-myeloablative hematopoietic cell transplantation. Cytotherapy. 2011;13(10): 1269-80.

30. Trzonkowski P, Szmit E, Mysliwska J, Dobyszuk A, Mysliwski A. $\mathrm{CD} 4{ }^{+} \mathrm{CD} 25^{+} \mathrm{T}$ regulatory cells inhibit cytotoxic activity of $\mathrm{T}$ $\mathrm{CD}^{+}$and NK lymphocytes in the direct cell-to-cell interaction. Clin Immunol. 2004;112(3):258-67.

31. Ghiringhelli F, Ménard C, Terme M, Flament C, Taieb J, Chaput N, Puig PE, Novault S, Escudier B, Vivier E, Lecesne A, Robert C, Blay JY, Bernard J, Caillat-Zucman S, Freitas A, Tursz T, Wagner-Ballon O, Capron C, Vainchencker W, Martin F, Zitvogel $\mathrm{L} . \mathrm{CD}^{+} \mathrm{CD} 25^{+}$regulatory $\mathrm{T}$ cells inhibit natural killer cell functions in a transforming growth factor-beta-dependent manner. J Exp Med. 2005;202(8):1075-85.

32. Grossman WJ, Verbsky JW, Barchet W, Colonna M, Atkinson JP, Ley TJ. Human T regulatory cells can use the perforin pathway to cause autologous target cell death. Immunity. 2004; 21(4):589-601.

33. Gondek DC, Lu LF, Quezada SA, Sakaguchi S, Noelle RJ. Cutting edge: contact-mediated suppression by $\mathrm{CD} 4{ }^{+} \mathrm{CD} 25^{+}$ regulatory cells involves a granzyme B-dependent, perforinindependent mechanism. J Immunol. 2005;174(4):1783-6.

34. Bazhin AV, Kahnert S, Kimpfler S, Schadendorf D, Umansky V. Distinct metabolism of cyclic adenosine monophosphate in regulatory and helper $\mathrm{CD}^{+}{ }^{+} \mathrm{T}$ cells. Mol Immunol. 2010;47(4): 678-84.

35. Kobie JJ, Shah PR, Yang L, Rebhahn JA, Fowell DJ, Mosmann TR. T regulatory and primed uncommitted CD4 $\mathrm{T}$ cells express CD73, which suppresses effector CD4 T cells by converting 5'adenosine monophosphate to adenosine. J Immunol. 2006; 177(10):6780-6.

36. Pandiyan P, Zheng L, Ishihara S, Reed J, Lenardo MJ. $\mathrm{CD} 4{ }^{+} \mathrm{CD} 25^{+} \mathrm{Foxp}^{+}$regulatory $\mathrm{T}$ cells induce cytokine deprivation-mediated apoptosis of effector $\mathrm{CD}^{+}{ }^{+} \mathrm{T}$ cells. Nat Immunol. 2007;8(12):1353-62.

37. Yu A, Malek TR. Selective availability of IL-2 is a major determinant controlling the production of $\mathrm{CD} 4{ }^{+} \mathrm{CD} 25^{+} \mathrm{Foxp}^{+} \mathrm{T}$ regulatory cells. J Immunol. 2006;177(8):5115-21.

38. Koreth J, Matsuoka K, Kim HT, McDonough SM, Bindra B, Alyea EP 3rd, Armand P, Cutler C, Ho VT, Treister NS, Bienfang DC, Prasad S, Tzachanis D, Joyce RM, Avigan DE, Antin JH, Ritz J, Soiffer RJ. Interleukin-2 and regulatory $T$ cells in graftversus-host disease. N Engl J Med. 2011;365(22):2055-66. 
39. Matsuoka K, Koreth J, Kim HT, Bascug G, McDonough S, et al. Low-dose interleukin-2 therapy restores regulatory $\mathrm{T}$ cell homeostasis in patients with chronic graft-versus-host disease. Sci Transl Med. 2013;5(179):179ra43.

40. Shin HJ, Baker J, Leveson-Gower DB, Smith AT, Sega EI, Negrin RS. Rapamycin and IL-2 reduce lethal acute graft-versushost disease associated with increased expansion of donor type CD $4{ }^{+} \mathrm{CD} 25^{+}$Foxp $^{+}$regulatory $\mathrm{T}$ cells. Blood. 2011;118(8): 2342-50.

41. Cohen JL, Trenado A, Vasey D, Klatzmann D, Salomon BL. $\mathrm{CD} 4(+) \mathrm{CD} 25(+)$ immunoregulatory $\mathrm{T}$ cells: new therapeutics for graft-versus-host disease. J Exp Med. 2002;196(3):401-6.

42. Joffre O, Santolaria T, Calise D, Al Saati T, Hudrisier D, Romagnoli P, van Meerwijk JP. Prevention of acute and chronic allograft rejection with $\mathrm{CD} 4{ }^{+} \mathrm{CD} 25^{+} \mathrm{Foxp}^{+}$regulatory $\mathrm{T}$ lymphocytes. Nat Med. 2008;14(1):88-92.

43. Hoffmann P, Ermann J, Edinger M, Fathman CG, Strober S. Donor-type CD4(+)CD25(+) regulatory $\mathrm{T}$ cells suppress lethal acute graft-versus-host disease after allogeneic bone marrow transplantation. J Exp Med. 2002;196(3):389-99.

44. Ermann J, Hoffmann P, Edinger M, Dutt S, Blankenberg FG, Higgins JP, Negrin RS, Fathman CG, Strober S. Only the $\mathrm{CD}_{2} 2 \mathrm{~L}^{+}$subpopulation of $\mathrm{CD} 4{ }^{+} \mathrm{CD} 25^{+}$regulatory $\mathrm{T}$ cells protects from lethal acute GVHD. Blood. 2005;105(5):2220-6.

45. Trenado A, Sudres M, Tang Q, Maury S, Charlotte F, Grégoire S, Bonyhadi M, Klatzmann D, Salomon BL, Cohen JL. Ex vivoexpanded $\mathrm{CD} 4{ }^{+} \mathrm{CD} 25^{+}$immunoregulatory $\mathrm{T}$ cells prevent graftversus-host-disease by inhibiting activation/differentiation of pathogenic T cells. J Immunol. 2006;176(2):1266-73.

46. Trenado A, Charlotte F, Fisson S, Yagello M, Klatzmann D, Salomon BL, Cohen JL. Recipient-type specific $\mathrm{CD} 4{ }^{+} \mathrm{CD} 25^{+}$ regulatory $\mathrm{T}$ cells favor immune reconstitution and control graftversus-host disease while maintaining graft-versus-leukemia. J Clin Invest. 2003;112(11):1688-96.

47. MiltenyiBiotec. Clinical applications. Immunotherapy. 2012. https:// www.miltenyibiotec.com/en/Clinical-applications/Immunotherapy/ Treg-cells.aspx. Accessed 25 Jun 2013.

48. BDBioscience. Regulatory $\mathrm{T}$ cells: essential regulators of the immune system. BD Biosci News Lett. 2009; ISBN: 23-1056200 .

49. Trzonkowski P, Myśliwska J, Pawelec G, Myśliwski A. From bench to bedside and back-the SENIEUR Protocol and the efficacy of influenza vaccination in the elderly. Biogerontology. 2009;10(1):83-94.

50. Trzonkowski P, Szmit E, Mysliwska J, Mysliwski A. $\mathrm{CD} 4{ }^{+} \mathrm{CD} 25^{+} \mathrm{T}$ regulatory cells inhibit cytotoxic activity of CTL and NK cells in humans: impact of immunosenescence. Clin Immunol. 2006;119(3):307-16.

51. Trzonkowski P, Debska-Slizień A, Jankowska M, Wardowska A, Carvalho-Gaspar M, Hak Ł, Moszkowska G, Bzoma B, Mills N, Wood KJ, Myśliwska J, Rutkowski B. Immunosenescence increases the rate of acceptance of kidney allotransplants in elderly recipients through exhaustion of $\mathrm{CD}^{+}{ }^{+} \mathrm{T}$-cells. Mech Ageing Dev. 2010;131(2):96-104.

52. Marek-Trzonkowska N, Mysliwiec M, Dobyszuk A, Grabowska M, Techmanska I, Juscinska J, Wujtewicz MA, Witkowski P, Mlynarski W, Balcerska A, Mysliwska J, Trzonkowski P. Administration of $\mathrm{CD} 4{ }^{+} \mathrm{CD} 25^{\text {high }} \mathrm{CD} 127$-regulatory $\mathrm{T}$ cells preserves $\beta$-cell function in type 1 diabetes in children. Diabetes Care. 2012;35(9):1817-20.

53. Marek-Trzonkowska N, Myśliwec M, Siebert J, Trzonkowski P. Clinical application of regulatory $\mathrm{T}$ cells in type 1 diabetes. Pediatr Diabetes. 2013. doi:10.1111/pedi.12029.

54. Trzonkowski P, Szaryńska M, Myśliwska J, Myśliwski A. Ex vivo expansion of $\mathrm{CD} 4(+) \mathrm{CD} 25(+) \mathrm{T}$ regulatory cells for immunosuppressive therapy. Cytometry A. 2009;75(3):175-88.
55. Hoffmann P, Boeld TJ, Eder R, Albrecht J, Doser K, Piseshka B, Dada A, Niemand C, Assenmacher M, Orsó E, Andreesen R, Holler E, Edinger M. Isolation of $\mathrm{CD} 4{ }^{+} \mathrm{CD} 25^{+}$regulatory T cells for clinical trials. Biol Blood Marrow Transplant. 2006;12(3): 267-74.

56. Godfrey WR, Ge YG, Spoden DJ, Levine BL, June CH, Blazar $\mathrm{BR}$, Porter SB. In vitro-expanded human CD4(+)CD25(+) T-regulatory cells can markedly inhibit allogeneic dendritic cellstimulated MLR cultures. Blood. 2004;104(2):453-6.

57. Milward K, Issa F, Hester J, Figueroa-Tentori D, Madrigal A, Wood KJ. Multiple unit pooled umbilical cord blood is a viable source of therapeutic regulatory $\mathrm{T}$ cells. Transplantation. 2013;95(1):85-93.

58. Gołąb K, Krzystyniak A, Marek-Trzonkowska N, Misawa R, Wang LJ, Wang X, Cochet O, Tibudan M, Langa P, Millis JM, Trzonkowski $\mathrm{P}$, Witkowski P. Impact of culture medium on $\mathrm{CD} 4{ }^{+} \mathrm{CD} 25^{\text {high }} \mathrm{CD} 127^{\text {low/neg }}$ Treg expansion for the purpose of clinical application. Int Immunopharmacol. 2013. doi:S15675769(13)00058-1.

59. Marek N, Bieniaszewska M, Krzystyniak A, Juscinska J, Mysliwska J, Witkowski P, Hellmann A, Trzonkowski P. The time is crucial for ex vivo expansion of $\mathrm{T}$ regulatory cells for therapy. Cell Transplant. 2011;11-12:1747-58.

60. Hippen KL, Merkel SC, Schirm DK, Sieben CM, Sumstad D, Kadidlo DM, et al. Massive ex vivo expansion of human natural regulatory $\mathrm{T}$ cells (T(regs)) with minimal loss of in vivo functional activity. Sci Transl Med. 2011;18(3):83ra41.

61. Battaglia M, Stabilini A, Roncarolo MG. Rapamycin selectively expands $\mathrm{CD}^{+}{ }^{+} \mathrm{CD} 25^{+} \mathrm{FoxP}^{+}$regulatory $\mathrm{T}$ cells. Blood. 2005; 105(12):4743-8.

62. Grzanka J, Leveson-Gower D, Golab K, Wang XJ, MarekTrzonkowska N, Krzystyniak A, Wardowska A, Mills JM, Trzonkowski P, Witkowski P. FoxP3, Helios, and SATB1: roles and relationships in regulatory $\mathrm{T}$ cells. Int Immunopharmacol. 2013. doi:S1567-5769(13)00046-5.

63. Piccirillo CA, Shevach EM. Control of $\mathrm{CD}^{+} \mathrm{T}$ cell activation by $\mathrm{CD}^{+} \mathrm{CD}^{2} 5^{+}$immunoregulatory cells. J Immunol. 2001;167: $1137-40$.

64. Marek N, Krzystyniak A, Ergenc I, Cochet O, Misawa R, Wang LJ, Gołąb K, Wang X, Kilimnik G, Hara M, Kizilel S, Trzonkowski P, Millis JM, Witkowski P. Coating human pancreatic islets with $\mathrm{CD} 4(+) \mathrm{CD} 25($ high$) \mathrm{CD} 127(-)$ regulatory $\mathrm{T}$ cells as a novel approach for the local immunoprotection. Ann Surg. 2011;254(3):512-8.

65. Canavan JB, Afzali B, Scottà C, Fazekasova H, Edozie FC, Macdonald TT, Hernandez-Fuentes MP, Lombardi G, Lord GM. A rapid diagnostic test for human regulatory T-cell function to enable regulatory T-cell therapy. Blood. 2012;119(8):57-66.

66. Trzonkowski P, Bieniaszewska M, Juścińska J, Dobyszuk A, Krzystyniak A, Marek N, Myśliwska J, Hellmann A. First-in-man clinical results of the treatment of patients with graft versus host disease with human ex vivo expanded $\mathrm{CD} 4^{+} \mathrm{CD} 25^{+} \mathrm{CD} 127^{-} \mathrm{T}$ regulatory cells. Clin Immunol. 2009;133(1):22-6.

67. Di Ianni M, Falzetti F, Carotti A, Terenzi A, Castellino F, Bonifacio E, Del Papa B, Zei T, Ostini RI, Cecchini D, Aloisi T, Perruccio K, Ruggeri L, Balucani C, Pierini A, Sportoletti P, Aristei C, Falini B, Reisner Y, Velardi A, Aversa F, Martelli MF. Tregs prevent GVHD and promote immune reconstitution in HLA-haploidentical transplantation. Blood. 2011;117(14): 3921-8.

68. Brunstein CG, Miller JS, Cao Q, McKenna DH, Hippen KL, Curtsinger $\mathrm{J}$, Defor $\mathrm{T}$, Levine $\mathrm{BL}$, June $\mathrm{CH}$, Rubinstein $\mathrm{P}$, McGlave PB, Blazar BR, Wagner JE. Infusion of ex vivo expanded $\mathrm{T}$ regulatory cells in adults transplanted with umbilical cord blood: safety profile and detection kinetics. Blood. 2011;117(3):1061-70. 
69. Komanduri KV, Champlin RE. Can Treg therapy prevent GVHD? Blood. 2011;117(3):751-2.

70. Edinger M, Hoffmann P. Regulatory T cells in stem cell transplantation: strategies and first clinical experiences. Curr Opin Immunol. 2011;23:679-84.

71. Suntharalingam G, Perry MR, Ward S, Brett SJ, Castello-Cortes A, Brunner MD, Panoskaltsis N. Cytokine storm in a phase 1 trial of the anti-CD28 monoclonal antibody TGN1412. N Engl J Med. 2006;355(10):1018-28.

72. Golab K, Leveson-Gower D, Wang XJ, Grzanka J, MarekTrzonkowska N, Krzystyniak A, Trzonkowski P, Witkowski P.
Challenges in cryopreservation of regulatory $\mathrm{T}$ cells (Tregs) for clinical therapeutic applications. Int Immunopharmacol. 2013. doi:S1567-5769(13)00043-X.

73. Wang XJ, Leveson-Gower D, Golab K, Wang LJ, MarekTrzonkowska N, Krzystyniak A, Wardowska A, Trzonkowski P, Witkowski P. Influence of pharmacological immunomodulatory agents on $\mathrm{CD} 4{ }^{+} \mathrm{CD} 25^{\text {high }} \mathrm{FoxP}^{+} \mathrm{T}$ regulatory cells in humans. Int Immunopharmacol. 2013. doi:S1567-5769(13)00057-X. 